\title{
Cockle Shell as Mixing Ingredient in Concrete: A Review
}

\author{
N. Mohamad ${ }^{1}$, K. Muthusamy $^{1^{*}}$ and M. A. Ismail ${ }^{2}$ \\ ${ }^{1}$ Faculty of Civil Engineering Technology, Universiti Malaysia Pahang, 26300 Gambang, Pahang, Malaysia \\ 2Department of Civil Engineering, Miami College of Henan University, Kaifeng, Henan, China
}

ABSTRACT - The demand for the population is boosting the production of edible and non-edible products that produce by-products that result in emissions being thrown as waste. The successful cockle trade also creates vestiges of cockle shell that are thrown away as waste. Despite the effects of climate change, industrial activity including calcareous and granite mining to satisfy the need for cement and concrete production, respectively, cannot be prevented as more structures are developed worldwide. The mechanical properties of concrete containing crushed cockle shell as partial fine aggregate, coarse aggregate and cement replacement were examined and reported in this paper. Cockle shell powder was used as cement replacement up to $75 \%$. To sum up, the use of cockle shell is an appealing option for the construction industry and sustainable green climate.
ARTICLE HISTORY

Received: $1^{\text {st }}$ June 2021

Revised: $30^{\text {th }}$ June 2021

Accepted: $10^{\text {th }}$ July 2021

\section{KEYWORDS}

Cockle shell powder

Cockle shell ash

Cement

Aggregate

Mechanical properties

\section{INTRODUCTION}

Actually, concrete is the most consumed commodity in the world among human-made products, with about three tonnes per capita every year [1]. Concrete is a material that involves the processing of cement, fine aggregate, coarse aggregate, and water as its raw material [2]. In order to achieve a solid form and a load bearing building material, the hydration of the cement connects the other components [3]. These raw materials have been taken from natural resources such as quarries, river beds, etc. [4]. Many forms of concrete are used annually in significant amounts [5]. Overall, concrete annual consumption reaches 25 billion tonnes [6], and with a total production volume of about 6 billion $\mathrm{m}^{3}$ in 2017 [7]. In Belgium, the total annual amount of concrete manufactured is estimated at 40.8 million tonnes (equal to 3.6 tons per capita), while precast concrete products are estimated at 12 million tons per annum (equal to 1.1 tonnes per capita) [8]. Due to its flexibility in strength, longevity and low maintenance costs, concrete is now regarded as the most important construction material. However, because to the extensive use of cement, natural fine and coarse aggregate, and energy, it has become one of the least sustainable commodities, increasing carbon dioxide $\left(\mathrm{CO}_{2}\right)$ emissions and depleting natural resources [9]. Continuous production of cement-based concrete is harmful and unsustainable, since it depletes available natural resources [10]. It should be remembered that 70-80\% of the concrete consists of lower inert carbon and lower cost aggregates [11]. Even a little gain in resource efficiency has a significant mitigating impact on the environmental impact of concrete manufacturing owing to its large size and ubiquity [12].

Cement acts as a binder in concrete. It is a compound that hardens and binds alternative items [13]. The cement sector plays a central part in developing nations' economic development. Demand for cement in construction drives production and, on the demand side, the production of cement is expected to continue to increase [14]. Ordinary Portland cement (OPC) production is progressively $9 \%$ per annum worldwide and about 4 billion tons are made $[15,16]$. The global production of cement output reaches 4.20 billion tonnes in 2019, 2.35 in China and 1.83 in the rest of the world [17,18] with 54-200 kg of cement kiln dust produced by each ton of Portland cement [19]. Cement production in Brazil was also about 55,000 thousand tonnes in 2019 (United States Geological Survey [20]. Global cement production reached 82,000 million tons in 2018, including 35,700 million tons in China, 12,460 million tons in the United States, 25,640 million tons in Thailand, 540 million tons in Turkey, 388 million tons in Brazil and 6976 million tons in other countries [21,22,23] suggesting that enormous cement production is increasing. Cement manufacturing is the second largest carbon dioxide $\left(\mathrm{CO}_{2}\right)$ industrial emitter, with about $7 \%$ of global emissions [24,25]. The cement industry is one of the major contributors to global climate change, releasing $2.2 \mathrm{Gt}$ of $\mathrm{CO}_{2}$ annually or $7 \%$ of total anthropogenic $\mathrm{CO}_{2}$ emissions, due to the energyintensive manufacturing process [26]. OPC production greenhouse gas emissions are approximately 1.5 billion tons (7$8 \%$ of total emissions) annually from various industries around the world [27]. These environmental degradations can also disrupt certain animal habitats, causing them to relocate, which in turn destroys the current ecosystem. However, this is an important issue because cement is often listed as a crucial material due to the large volume needed in building energy technologies and its high effect on the environment [28].

Quarries that are often utilised in the processing of igneous, sedimentary, and metamorphic rock deposits are often utilised to produce natural aggregates [29]. The aggregate makes up around 70-80\% of the overall concrete volume. Computed to be over 48 billion metric tonnes of aggregate materials, the world's construction sector is believed to use this amount of aggregate [30]. The components are comprised of about half river and ocean fine and coarse aggregates and about half from mountains, which make up more than 50\% of the overall mixing components. Approximately 9 
billion tonnes of this resource will be needed annually by 2050 [31]. rising at an average annual rate of $7.7 \%$ through 2022, aggregate demand for concrete production is projected to increase to 66.2 billion metric tonnes [31]. The need for building is growing in many regions of the globe, which causes the sand supply sector to rise. Generally, sand is collected from land quarries, river beds or from marine and coastal mining. To date, it takes about 50 billion tons of sand per year [32]. Owing to the high demand on the construction side, sand is becoming scarce in certain regions of the world and as human consume sand more quickly than their stocks replenish with natural creation [3].

The lack of natural mineral resources is expected to become even more prevalent in 2019, when total annual consumption of natural aggregates is estimated to surpass 51.7 billion tonnes [33,34]. Almost all nations have a lack of natural aggregates and rising pricing [35]. A case may even be made to point out that in certain nations, aggregates are imported to help ease the problem of localised natural aggregate scarcity [12]. It's now becoming more and more difficult to find big amounts of high-quality limestone, which is why cement is harder and more expensive to make. Today, the Earth is short on landfill space and there are imbalances in the ecosystem [36]. River sand is the most often utilised construction material because of its exceptional characteristics. Unrestricted usage of local natural resources in small geographic regions will, however, fail to meet future demands, and hence will be lost in the future [11]. Aggregate mining threatens to decimate the natural beauty that is teeming with plants and wildlife, transforming it into a desolate landscape that faces erosion during the rainy seasons [37]. One of the most important protein sources in the South East Asian zone is the South East Asian cockle (Anadara granosa), which lives mostly on intertidal mudflats. Sea mollusk meat is a common ingredient in South East Asian dishes [38]. Europe produced an average of 14,000 to 26,000 tonnes of cockles per year from 2014 to 2017 (Table 1), with UK, Spain, Portugal, and Denmark accounting for more than half of this output [39]. Clams have a wildly fluctuating value, mostly depending on the supply-demand balance. Their value relative to other forms of shellfish is low. Generation of $\$ 6.3$ million yearly comes from the harvest of around 5543 tonnes of cockle shell, which might be used as shell aggregate [39].

Table 1. Annual reported European harvest (tonnes) of Cerastodermaedule by country for 2014 to 2017

\begin{tabular}{lllll}
\hline \multirow{2}{*}{ Country } & \multicolumn{4}{l}{ Year } \\
\cline { 2 - 5 } & 2014 & 2015 & 2016 & 2017 \\
\hline UK & 10171 & 11169 & 5036 & 5997 \\
Denmark & 6081 & 7699 & 5917 & 7924 \\
Portugal & 1991 & 4700 & 1835 & 5063 \\
Spain & 1195 & 2410 & 1561 & 2846 \\
France & 228 & 145 & 80 & 259 \\
Ireland & 3 & 0 & 222 & 441 \\
Sweden & 0 & 2 & 0 & 0 \\
European total & 19669 & 26125 & 14651 & 22530 \\
\hline \multicolumn{5}{c}{ Sources: FAO [40] }
\end{tabular}

\section{MATERIAL CHARACTERISTICS}

\section{Physical Aspect}

A family category of double-shelled cardiidae called "cockle shell" is made in a variety of ways, including on the exterior [41]. A shell's ridges grow more uniformly with time, and the older cockles have more consistent patterns of ridges than the younger ones, which causes the number of ridges to reveal the age of the cockle. They may grow to between 60 and 60 millimetres in width, and can survive up to 20 years. When the shell grows, it makes the cockle stronger and heavier, so protecting it from damage [42]. As observed in Figure 1, the outside surface is white, yellowish, or brownish. Once lines of development have been established, they are not reversible. The adductor muscle scar's inside surface is greyish white with a brownish or light purple tinge on or around the muscle scar's back [43]. In the other hand, when cockle shell waste was used as a gross aggregate in plain concrete, these shells were typically in uncrusted shape with a maximum size of between 10 and $20 \mathrm{~mm}$. As seen in Table 3, the specific gravity of the aggregate cockle shells was observed to be within the range of 2.09-2.64, which is close to standard aggregates [44,45]. In general, crushed cockle shell powder and cockle shell ash have been used as a cement substitute with a scale of less than $75 \mu \mathrm{m}$ (Table 2). The scale of the samples taken in this analysis ranged from 25 to $50 \mathrm{~mm}$ prior to sea shell grinding [46]. Cockle shell powder appears in a white colour while cockle shell ash appears in a light greyish colour due to a burning reaction (Figure 2). The composition of cockle shell ash is also rougher than cockle shell powder. Other properties of the cockle shell as a cockle shell mixture, powder and ash are seen in Table 2. In comparison, Figure 3 to Figure 5 displays the morphologies of the cockle shell before and after pulverisation. 
Table 2. Physical properties of cockle shell used in previous studies

\begin{tabular}{ccccccc}
\hline Reference & $\begin{array}{c}\text { Replacement } \\
\text { type }\end{array}$ & Size & $\begin{array}{c}\text { Specific } \\
\text { gravity } \\
(\boldsymbol{\%})\end{array}$ & $\begin{array}{c}\text { Blaine- } \\
\text { specific } \\
\text { surface area }\end{array}$ & $\begin{array}{c}\text { Fineness } \\
\text { modulus } \\
(\boldsymbol{\%})\end{array}$ & $\begin{array}{c}\text { Water } \\
\text { absorption } \\
(\boldsymbol{\%})\end{array}$ \\
\hline$[47]$ & Cement & $75 \mu \mathrm{m}$ & 2.82 & $8299 \mathrm{~cm}^{2} / \mathrm{g}$ & $4.22 \%$ passing & 0.15 \\
{$[48]$} & Cement & $23.97 \mu \mathrm{m}$ & 2.07 & & - & - \\
{$[46]$} & Cement & $60 \mu \mathrm{m}$ & 1.39 & $3800 \mathrm{~cm}^{2} / \mathrm{g}$ & - & 12.10 \\
{$[49]$} & Cement & $75 \mu \mathrm{m}$ & - & - & - & - \\
{$[49]$} & Cement & $75 \mu \mathrm{m}$ & - & - & - & - \\
{$[45]$} & Coarse & $10-14 \mathrm{~mm}$ & - & - & - & - \\
{$[44]$} & Coarse & $20 \mathrm{~mm}$ & 2.50 & - & 7.53 & 20.15 \\
{$[51,52]$} & Coarse & $6.30-9.50 \mathrm{~mm}$ & 2.09 & - & - & 1.8 \\
{$[53]$} & Coarse & $4.75-6.30 \mathrm{~mm}$ & 2.64 & - & - & 2.5 \\
{$[54]$} & Cement & $0.6 \mu \mathrm{m}$ & - & - & - & 0.1 \\
{$[55]$} & Cement & $5.77 \mu \mathrm{m}$ & 2.33 & - & - & - \\
\hline
\end{tabular}
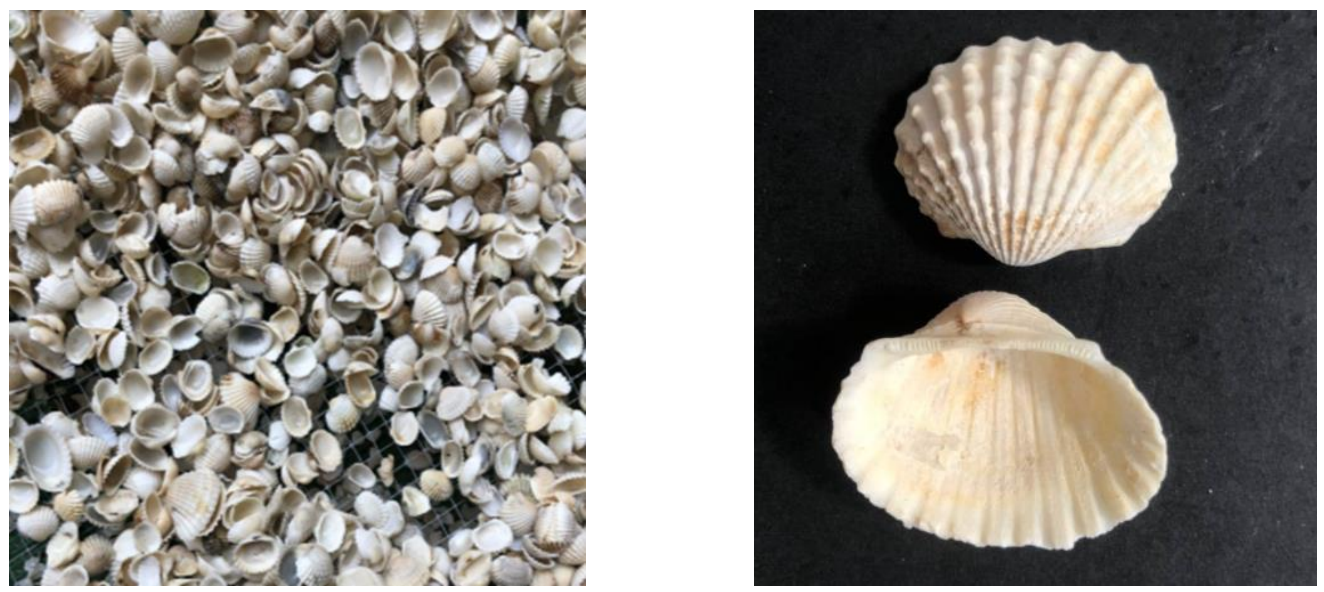

Figure 1. Cockle shell sample before crushing (left) and cockle shell texture and colour (right)
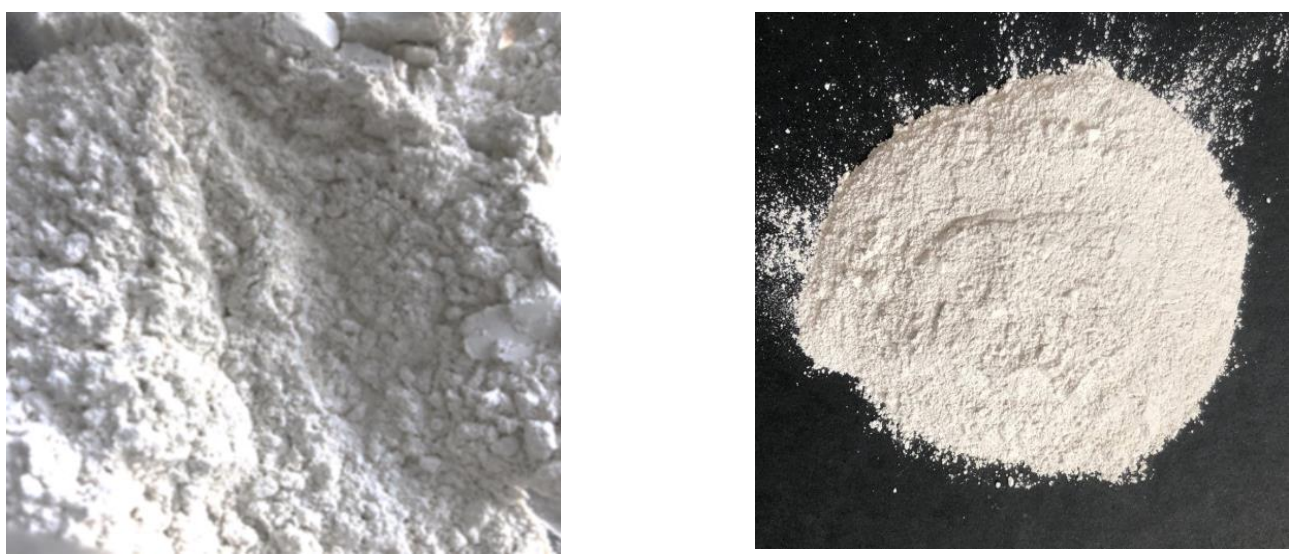

Figure 2. Cockle shell powder (left) and cockle shell greyish ashes (right) 


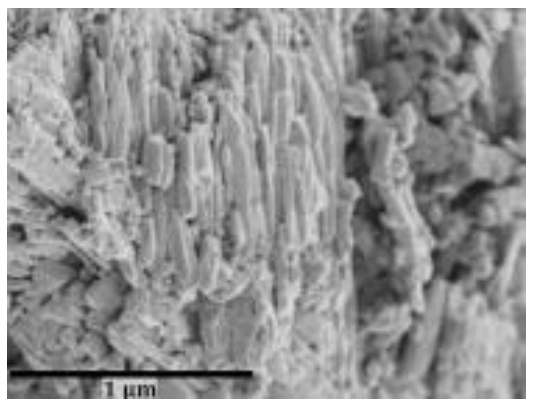

Figure 3. SEM picture of cockle shell powder [47]

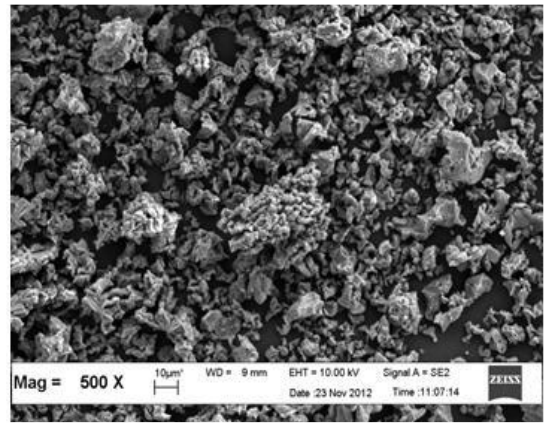

Figure 4. SEM picture of cockle shell ashes [55]

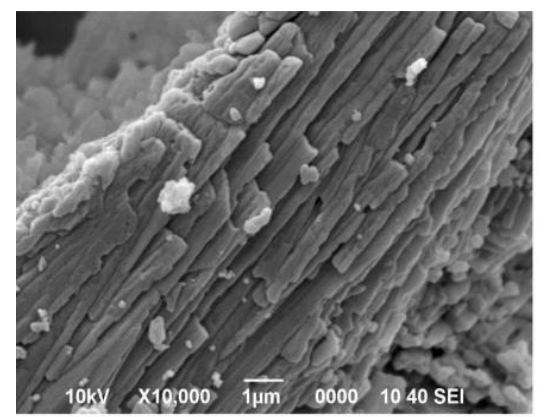

Figure 5. SEM picture of cockle shell aggregate [52]

\section{Chemical composition of Cockle Shell}

Cockle shell has a very high calcium content. The material is so important that it is typically composed of calcium carbonate of prismatic layers giving the shell structure a high strength, low mass and low coefficient of thermal conductivity [56,47]. The chemical structure of the raw cockle shell is shown in Table 3. Calcium carbonate content $\mathrm{CaCO}_{3}$ is more than $90 \%$ by weight in cockle shells $[56,57,58,49,50,59]$ and is almost equivalent to limestone $[48,46]$. Interestingly, $\mathrm{CaCO}_{3}$ is one of the four main raw materials making cement [60] while the other major cement compounds are dicalcium silicate $\left(\mathrm{C}_{2} \mathrm{~S}\right)$, tricalcium silicate $\left(\mathrm{C}_{3} \mathrm{~S}\right)$, tricalcium aluminate $\left(\mathrm{C}_{3} \mathrm{~A}\right)$ and tetracalcium aluminoferite; $\left(\mathrm{C}_{4} \mathrm{AF}\right)$.

Table 3. Chemical properties of raw cockle shell in percentage (\%)

\begin{tabular}{cccccccccc}
\hline \multirow{2}{*}{ Reference } & \multicolumn{8}{c}{ Mineral Composition (\%) } \\
\cline { 2 - 10 } & $\mathbf{C a C}$ & $\mathbf{M g}$ & $\mathbf{S i}$ & $\mathbf{N a}$ & $\mathbf{P}$ & $\mathbf{A l}$ & $\mathbf{S i}$ & $\mathbf{S r}$ & Others \\
\hline$[56]$ & 98.99 & 0.51 & 0.078 & - & - & - & - & - & $<0.1$ \\
{$[61]$} & 98.70 & 0.05 & - & 0.9 & - & - & - & - & $<0.1$ \\
{$[41]$} & 98.7 & 0.05 & - & 0.9 & 0.02 & - & - & - & 0.2 \\
{$[54]$} & 97.23 & 0.54 & 0.63 & - & - & 1.02 & 0.63 & 0.34 & 0.24 \\
\hline
\end{tabular}




\section{MECHANICAL PROPERTIES OF COCKLE SHELL CONCRETE}

Table 4 summarises previous research on cockle shell's effect on concrete characteristics. Using cockle shell affects the compressive, flexural, tensile, and elastic strengths of concrete, as well as its modulus of elasticity. An abundance of relevant data is available on the compressive strength of concrete. Effect on each of these mechanical characteristics is explored in the following sub-sections. As reported by [62] and has also been observed by the author that the behavior of concrete depending on the source and the proportions of its individual components. Environmental conditions, sample hardening history, and non-standardized test parameters and procedures make it difficult to obtain general results on the mechanical properties of concrete.

Table 4. Effects of cockle shell on mechanical properties of concrete

\begin{tabular}{|c|c|c|c|c|c|c|}
\hline \multirow[b]{2}{*}{ Reference } & \multirow{2}{*}{$\begin{array}{l}\text { Cockle shell content } \\
(\%)\end{array}$} & \multirow{2}{*}{$\begin{array}{l}\text { Replacement } \\
\text { type }\end{array}$} & \multicolumn{4}{|l|}{ Result } \\
\hline & & & $\begin{array}{l}\text { Compressive } \\
\text { Strength }\end{array}$ & $\begin{array}{l}\text { Flexural } \\
\text { Strength }\end{array}$ & $\begin{array}{l}\text { Tensile } \\
\text { Strength }\end{array}$ & $\begin{array}{l}\text { Modulus of } \\
\text { Elasticity }\end{array}$ \\
\hline$[46]$ & $\begin{array}{l}0,4,5,6,7,8,9,10 \\
15,20,30\end{array}$ & Cement & $\begin{array}{l}\text { Increase at } 8 \% \\
\text { replacement }\end{array}$ & $\begin{array}{l}\text { Decreased } \\
\text { for all } \\
\text { replacement }\end{array}$ & - & - \\
\hline$[55]$ & $0,5,10,15,25,50$ & Cement & $\begin{array}{l}\text { Decreased for all } \\
\text { replacement }\end{array}$ & - & $\begin{array}{l}\text { Increase at } \\
5 \% \\
\text { replacement }\end{array}$ & $\begin{array}{l}\text { Increased at } \\
10 \% \\
\text { replacement }\end{array}$ \\
\hline [47] & $0,5,10,1520$ & Cement & $\begin{array}{l}\text { Decreased for all } \\
\text { replacement }\end{array}$ & - & - & - \\
\hline [49] & $0,2,4,6,8$ & Cement & $\begin{array}{l}\text { Decreased for all } \\
\text { replacement }\end{array}$ & $\begin{array}{l}\text { Increase for } \\
\text { all } \\
\text { replacement }\end{array}$ & $\begin{array}{l}\text { Increase for } \\
\text { all } \\
\text { replacement }\end{array}$ & $\begin{array}{l}\text { Decreased } \\
\text { for all } \\
\text { replacement }\end{array}$ \\
\hline$[45]$ & $\begin{array}{l}0,5,10,15,20,25, \\
30\end{array}$ & & $\begin{array}{l}\text { Decreased for all } \\
\text { replacement }\end{array}$ & - & - & - \\
\hline$[50]$ & 4 & Cement & $\begin{array}{l}\text { Decreased for all } \\
\text { replacement }\end{array}$ & - & $\begin{array}{l}\text { Decreased } \\
\text { for all } \\
\text { replacement }\end{array}$ & - \\
\hline [44] & $0,10,20,30$ & $\begin{array}{l}\text { Coarse } \\
\text { aggregate }\end{array}$ & Decreased at $30 \%$ & - & $\begin{array}{l}\text { Decreased at } \\
30 \% \\
\text { replacement }\end{array}$ & - \\
\hline$[51]$ & $0,25,50,75$ & $\begin{array}{l}\text { Coarse } \\
\text { aggregate }\end{array}$ & $\begin{array}{l}\text { Decreased for all } \\
\text { replacement }\end{array}$ & - & - & - \\
\hline$[53]$ & $0,5,10,15,20,25$ & $\begin{array}{l}\text { Coarse } \\
\text { aggregate }\end{array}$ & $\begin{array}{l}\text { Decreased for all } \\
\text { replacement }\end{array}$ & - & & - \\
\hline$[54]$ & $0,10,25,40,50$ & Cement & $\begin{array}{l}\text { Increase for all } \\
\text { replacement }\end{array}$ & - & - & - \\
\hline$[52]$ & $0,25,50,75$ & $\begin{array}{l}\text { Coarse } \\
\text { aggregate }\end{array}$ & $\begin{array}{l}\text { Decreased for all } \\
\text { replacement }\end{array}$ & - & - & - \\
\hline$[63]$ & $0,5,10,15,20$ & $\begin{array}{l}\text { Fine } \\
\text { aggregate }\end{array}$ & $\begin{array}{l}\text { Increase for all } \\
\text { replacement }\end{array}$ & $\begin{array}{l}\text { Increase for } \\
\text { all } \\
\text { replacement }\end{array}$ & - & - \\
\hline \multirow[t]{2}{*}{ [41] } & $\begin{array}{l}0,5,10,15,20,25, \\
30\end{array}$ & $\begin{array}{l}\text { Fine } \\
\text { aggregate }\end{array}$ & $\begin{array}{l}\text { Increase at } 10 \% \\
\text { replacement }\end{array}$ & - & $\begin{array}{l}\text { Decrease for } \\
\text { all } \\
\text { replacement }\end{array}$ & \\
\hline & & $\begin{array}{l}\text { Coarse } \\
\text { aggregate }\end{array}$ & $\begin{array}{l}\text { Increase at } 25 \% \\
\text { replacement }\end{array}$ & - & $\begin{array}{l}\text { Decrease for } \\
\text { all } \\
\text { replacement }\end{array}$ & - \\
\hline
\end{tabular}




\section{Compressive Strength}

Compressive strength is the most common mechanical behaviour studied in concrete science. The findings of previous research on the integration of cement substitution are seen in Table 4. Most of the studies indicated that the addition of cockle shells to concrete contributes to a decrease in early concrete strength (Table 4). If a cockle shell is replaced as a partial cement substitute in concrete, the strength of a cockle shell ash mixture is stated to be lower than regular concrete $[49,55,47]$. However, the percentage of strength increased over a long curing period (up to 90 days) relative to regular concrete, particularly with CSA5 and CSA15 [55]. Hazurina [15] have showed that the compressive strength of concrete declined with a higher volume of cockle shell ash used. However, CSA5 and CSA10 showed compressive strength above $35 \mathrm{~N} / \mathrm{m}$ at 28 days. It can be inferred that the substitution of $5 \%$ to $10 \%$ of cement by a cockle shell with a low amorphous content and low LOI values, as well as a high $\mathrm{CaCO}_{3}$, has proven to be an effective new concrete [55]. Meanwhile, AlZubaidi [54] showed an improvement in compressive strength with an increase in cockle shell powder ratio. This activity is thought to be related to the intrinsic hardness of the powder particules. Each powder particle in the volume of the specimen is known to be a centre of resistance to external compression. As a result, the increase in these tolerance centres would result in a homogeneous distribution of external force over the whole specimen system and, eventually, an increase in compressive power. This indicates that the inclusion of coke shell powder has contributed to a decrease in the failure process under external load [54]. Another analysis came to the same conclusion that it can be argued that cockle shell concrete is more able to tolerate load resistance than control specimens. For the initial 14 days of the evaluation, all cockle shell concrete achieved rapid strength growth as presented in Figure 6. However, the drop in intensity was significantly detected from day 14 to day 28 . There was no substantial growth of cockle shell concrete after 28 days, although the control specimens tended to improve their intensity to a limited degree. These findings suggest that the strength of the cockle shell concrete depends on the volume of the replacement material of which the lower quantity of the replacement material yields at higher strength. Cockle shell concrete with a reduced volume of sand is assumed to contribute to isolation and bleeding of concrete. Adding more sand makes the concrete thicker and heavier. Apart from that, the disproportionate volume of sand used induces high cement use in concrete [64].

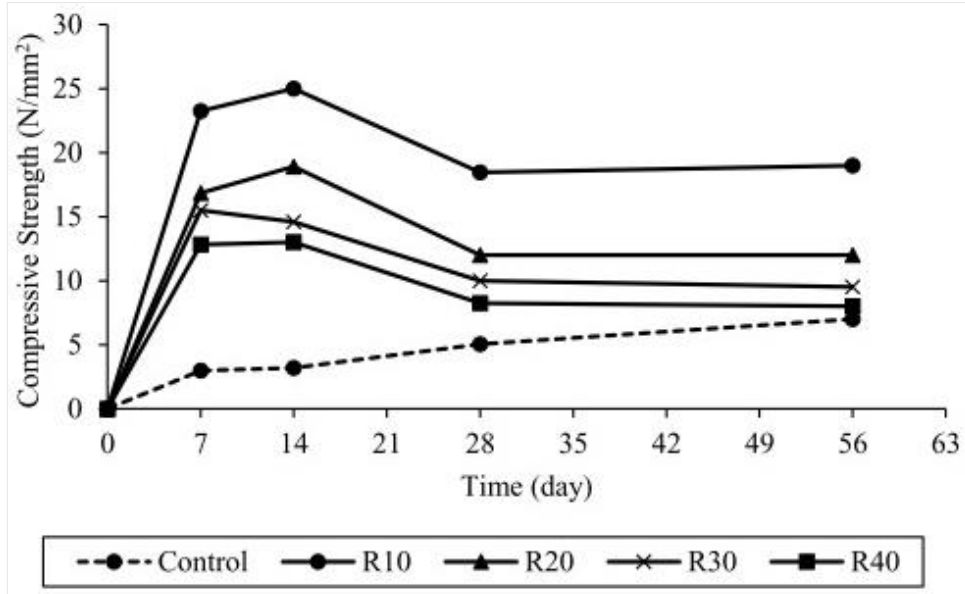

Figure 6. The effect of cockle shell as cement replacement on compressive strength [64]

The coarse aggregate, when mixed proportionally with cockle shell, may boost the concrete strength, according to researchers who study the use of cockle shell as a gross aggregate substitute. It is possible to demonstrate that a blend formed of a $20 \%$ cockle shell replacement displays the greatest compressive strength when compared to concrete created just from the cement and the aggregate. The rougher surface roughness of the coke shell lends strength to the bond and contributes to inter-particle friction, both of which contribute to the concrete's compressive strength. It can be shown in Figure 7 that a cockle shell content of too much greatly reduces the concrete's compressive strength [41,45]. It is justified because the cement paste won't be able to bind adequately if there is too much cockle shell, which increases the effective surface area [45]. In the paper by Raju [53], it has been discovered that when $15 \%$ of the coarse aggregate and $20 \%$ of the fine aggregate are used, the maximum compressive strength of concrete is found. The compressive power of this combination is $43.7 \mathrm{MPa}$ while that of standard concrete is $30 \mathrm{MPa}$. The potential explanation for this effect may be that the C-S-H gel (formed due to the high content of silica in granite powder) strengthens the properties of the cockle shell by forming a coating over it [53]. 


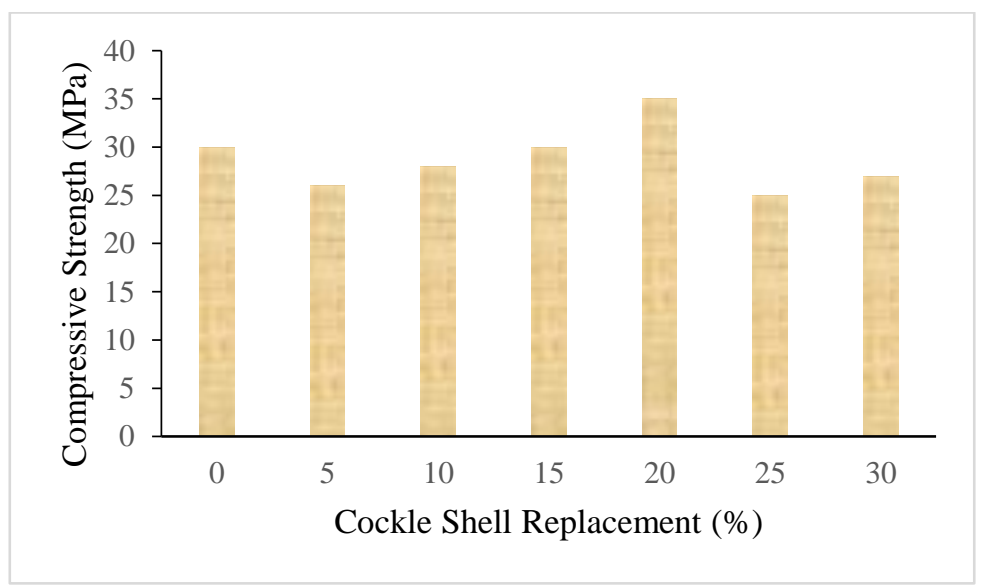

Figure 7. Compressive strength results for all replacement at 28 days [45]

In the other hand, by referencing Figure 8 , it can be seen that integrating up to $20 \%$ crushed cockle shell waste improves compressive strength. Finely crushed aggregate is presumed to serve as a filler to make the inside of the concrete construction more compact. The more weight it can carry, the more concrete may be used [63].

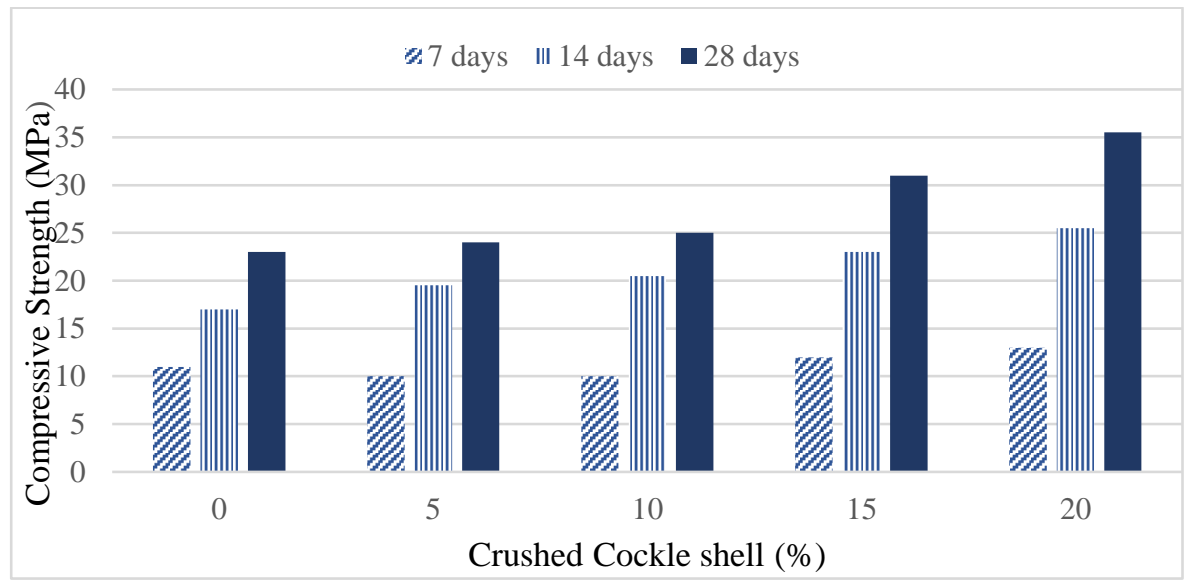

Figure 8. Compressive strength results for all replacement as sand replacement [63]

\section{Flexural Strength}

Cement replacement with flexural strength integration research is included in Table 4. It may be inferred from the Olivia [49] study that seashell concrete continues to gain strength after 28 and 91 days (refer Figure 9). Because of the calcium component of the cement, the paste and aggregate bonds were made stronger. Bonding has reduced tension qualities like as tensile and flexural strength. This will assist enhance the composite motion between steel reinforcing bars and concrete [49]. Meanwhile, the findings reveal that the flexural intensity declines with the ash of the cockle shell. At 90 days of curing, a decrease of around $10 \%$ for concrete with a cockle shell ash content from 5\% to $10 \%$ compared to OPC concrete [55].

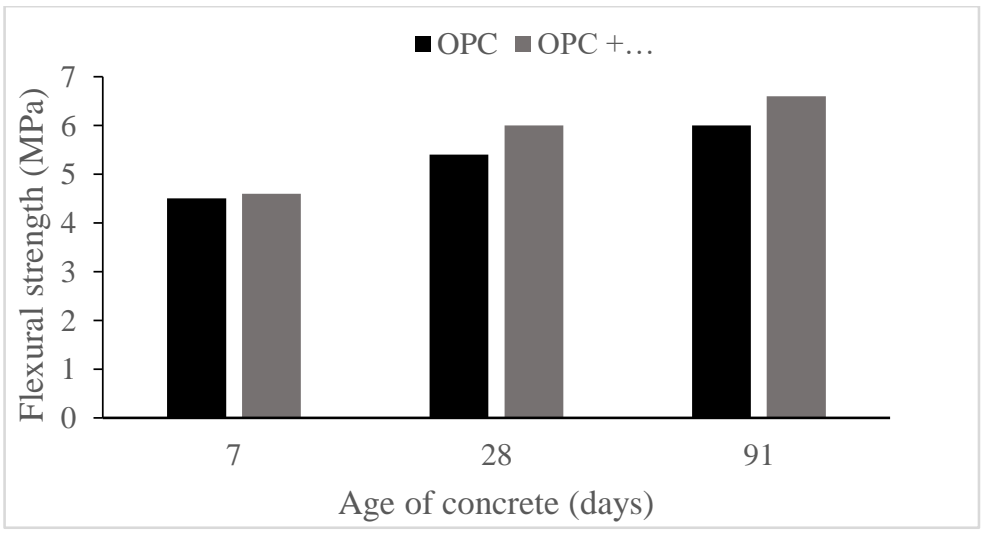

Figure 9. Flexural strength of concrete with $4 \%$ cockle shell powder replacement as cement [49] 
According to researchers that handle cockle shell as a fine aggregate in concrete, the inclusion of crushed cockle shell waste up to $20 \%$ impacts flexural strength, as seen in Figure 10 [63]. However, flexural strength on cockle shell as coarse aggregate substitution in concrete are not investigated yet.

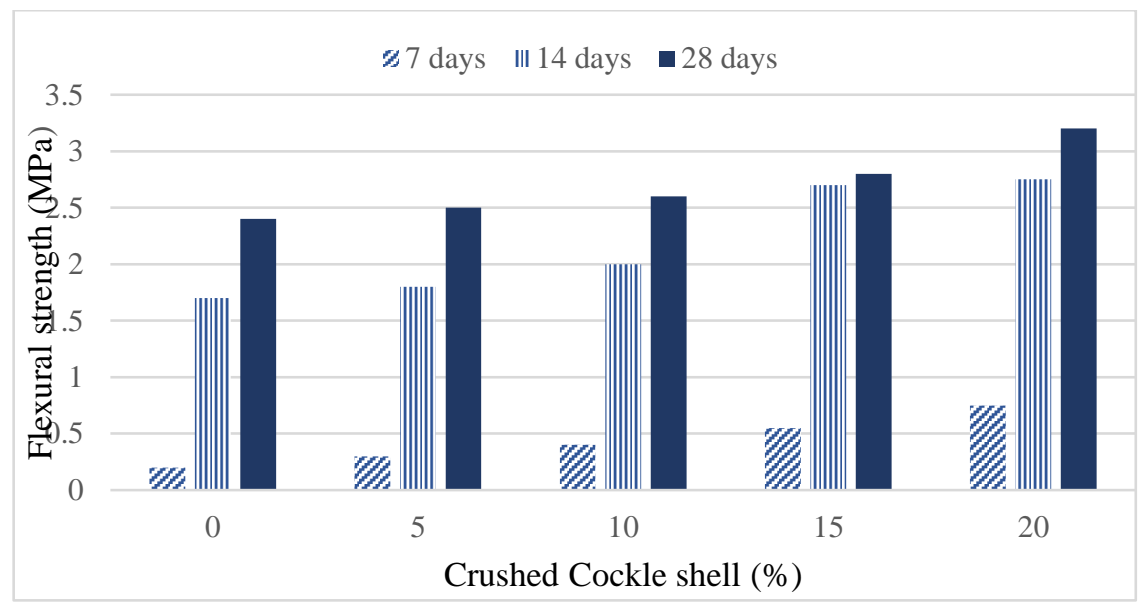

Figure 10. Flexural strength of crushed cockle shell as fine aggregate in concrete [63]

\section{Tensile Strength}

Table 4 summarises past studies on the integration of cement replacement at tensile strength. According to Olivia [49] experiment, the tensile strength of both OPC and OPC cockle shells increased steadily. After 28 days, the tensile strength of cockle shell concrete increased much more than that of OPC. It has been reported that the addition of 5\% cockle ash increased the tensile strength significantly. This high tensile strength was probably achieved by improved interfacial bonding between the cement paste and particles. The field seashell will raise the density of the concrete, thereby altering the ITZ at the interface between the aggregate and the cement paste [49]. Olivia [50] discovered that the tensile strength of OPC cockle with a $4 \%$ cockle shell ash replacement was substantially less than that of OPC concrete. Other studies obtained similar findings regarding the tensile strength of OPC sea shells after the interaction of the aggregate-cement paste's bonding strength with the cement replacement [50]. Additionally, Hazurina [55] observed that combining concrete with cockle shell ash results in a significant increase in curing time of up to 90 days (refer Figure 11). As a consequence, the lengthy curing cycle is necessary to assure the uniformity of the concrete's strength as a consequence of the pozzolanic reaction and cement hydration [55].

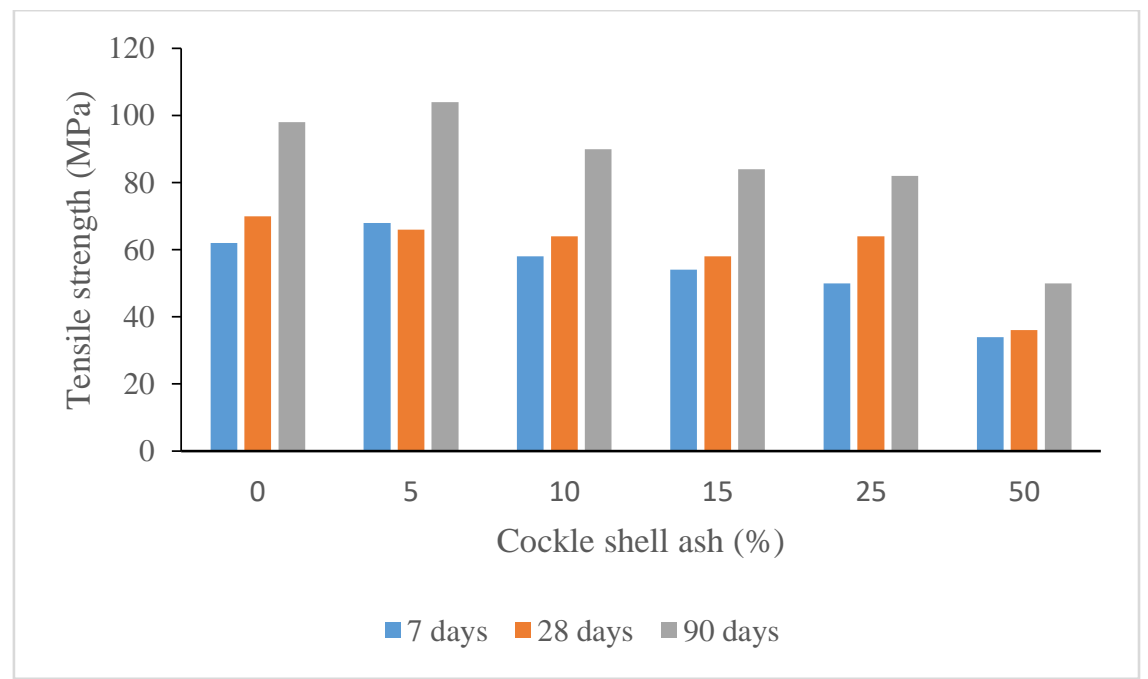

Figure 11. Tensile strength of cockle shell ash as cement replacement in concrete [55]

According to researchers who treat cockle shell as a gross aggregate in concrete, the tensile strength of concrete at 7 days and 28 days is steadily decreased as the percentage of substitution rises. However, a replacement between $10 \%$ and $20 \%$ is found to be more than conventional concrete and a replacement of $30 \%$ is found to be much smaller than anticipated (Table 5) [44]. Similar to Ramakhrishna [41], concrete is extremely fragile under stress as the cockle shell is substituted as a gross aggregate due to its quickly fractured existence and cannot withstand direct tension. It can be seen 
through the results shown in Figure 12. Concrete cracks form as the load is exposed to tensile forces. It is therefore important to infer the tensile strength of the concrete at which the concrete member can crack.

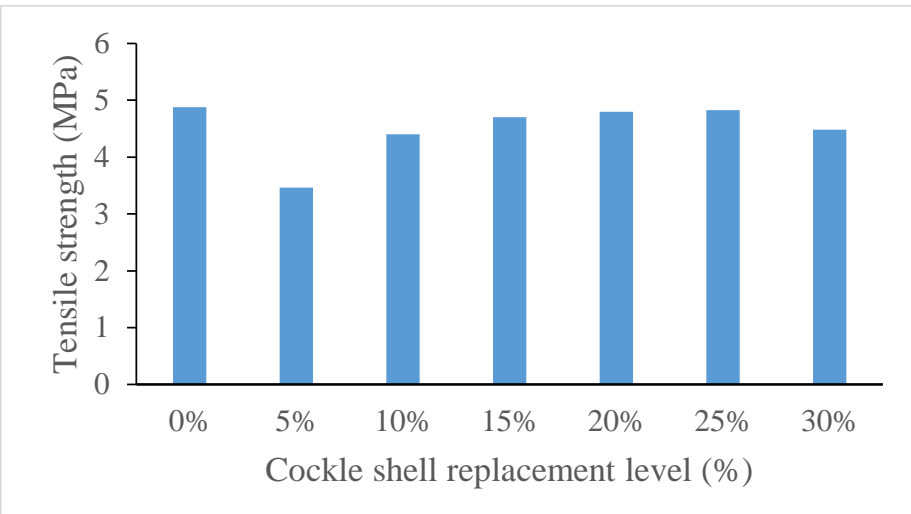

Figure 12. Splitting tensile strength of concrete containing various content of cockle shell as coarse aggregate at 28 days [41]

Table 5. Tensile Strength Results [44]

\begin{tabular}{cccc}
\hline $\begin{array}{c}\text { Sample } \\
\text { no }\end{array}$ & $\begin{array}{c}\text { \% Replacement of fly ash and } \\
\text { seashell }\end{array}$ & $\begin{array}{c}\text { Split tensile strength } \mathrm{N} / \mathrm{mm}^{2} \\
\text { (7days) }\end{array}$ & $\begin{array}{c}\text { Split tensile strength N/mm } \\
(28 \text { days })\end{array}$ \\
\hline 1 & 0 & 2.6 & 2.8 \\
2 & 10 & 2.8 & 2.9 \\
3 & 20 & 2.9 & 2.95 \\
4 & 30 & 2.5 & 2.5 \\
\hline
\end{tabular}

\section{Modulus of Elasticity}

The modulus of elasticity of concrete refers to the material's ability to bend under weight and then restore to its original proportions when the force is removed. Hazurina [55] found that a combination of 5\% CSA and more than $10 \%$ as a cement alternative yielded a low modulus of elasticity (55). Olivia [49] found that the modulus of elasticity of cockle shell concrete was lower than the OPC (refer Figure 13). However, the elasticity of seashell concrete increased above OPC standards. Cement paste interfaces have a large impact on the modulus of concrete. improved friction qualities, such as the modulus of elasticity of seashell concrete As seashell concrete aged, the modulus of elasticity rose. Concrete including ground shell had substantially superior voltage characteristics, but poorer compressive strength and modulus of elasticity [49]. Conversely, modulus of elasticity for sand replacement and coarse replacement have not been studied yet.

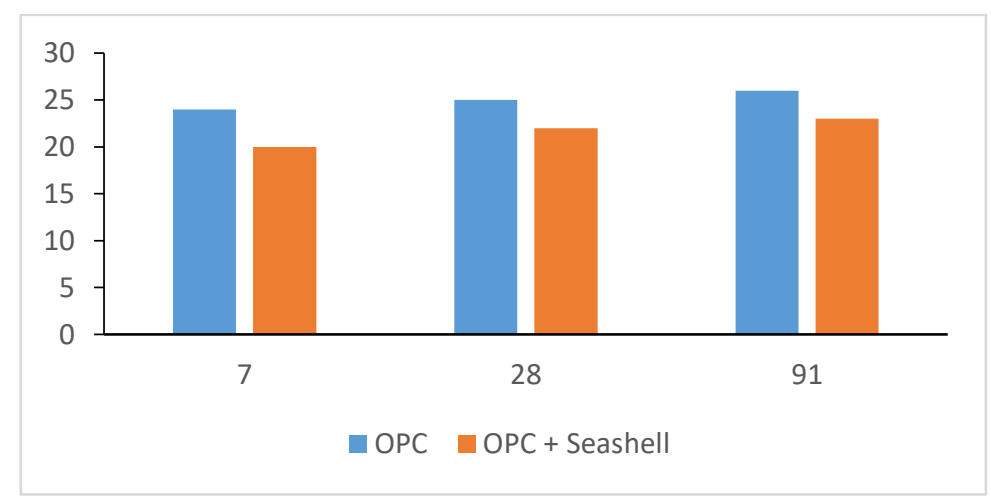

Figure 13. Modulus of Elasticity of OPC and seashell concrete at 7, 28, and 91 days [49]

\section{CONCLUSION}

This article discusses the qualities of cockle shell and the mechanical characteristics of cockle shell-containing concrete. The world's burgeoning population need an ever-increasing quantity of concrete. However, concrete manufacture has a severe impact on the environment, resulting in the depletion of these resources. Additionally, such 
reuse of waste materials may have economic advantages. Cockle shell is one of these plentiful waste items, whose disposal is a significant difficulty in and of itself. By substituting cockle shell up to a specified percentage as a mixing material in concrete, the strength of the concrete is increased. Utilizing plentiful locally sourced waste materials as a substitute for non-renewable ingredients in concrete manufacturing would benefit both the environment and the economy. Additionally, it contributes to the reduction of excessive quarrying activity for raw material extraction.

\section{ACKNOWLEDGEMENT} 200388.

The authors express their gratitude for the financial support provided by Universiti Malaysia Pahang through PGRS

\section{REFERENCES}

[1] Protasio, F. N., de Avillez, R. R., Letichevsky, S., \& de Andrade Silva, F. (2021). The use of iron ore tailings obtained from the Germano dam in the production of a sustainable concrete. Journal of Cleaner Production, 278, 123929. doi:10.1016/j.jclepro.2020.123929

[2] Jalal, M., Nassir, N., \& Jalal, H. (2019). Waste tire rubber and pozzolans in concrete: a trade-off between cleaner production and mechanical properties in a greener concrete. Journal of Cleaner Production, 238, 117882. doi:10.1016/j.jclepro.2019.117882

[3] Kaufmann, J. (2020). Evaluation of the combination of desert sand and calcium sulfoaluminate cement for the production of concrete. Construction and Building Materials, 243, 118281. doi:10.1016/j.conbuildmat.2020.118281

[4] Velumani, P., \& Manikandan, P. (2020). Contribution to the development of tiles made of paper board sludge. Advances in Environmental Research, 9(4), 285-294. https://doi.org/10.12989/aer.2020.9.4.285

[5] Alabduljabbar, H., Mohammadhosseini, H., Tahir, M. M., \& Alyousef, R. (2020). Green and sustainable concrete production using carpet fibers waste and palm oil fuel ash. Materials Today: Proceedings, In Press, corrected proof, Available online 28 April 2020. doi:10.1016/j.matpr.2020.04.047

[6] Afroughsabet, V., Geng, G., Lin, A., Biolzi, L., Ostertag, C., P., Monteiro, P., J., M. (2019). The influence of expansive cement on the mechanical, physical, and microstructural properties of hybrid-fiber-reinforced concrete. Cement and Concrete Composites, 96, 21-32. doi: 10.1016/j.cemconcomp.2018.11.012

[7] Unicem. Available at: https://www.unicem.fr

[8] Zhao, Y., Yu, M., Xiang, Y., Kong, F., \& Li, L. (2020). A sustainability comparison between green concretes and traditional concrete using an emergy ternary diagram. Journal of Cleaner Production, 256, 120421. https://doi.org/10.1016/j.jclepro.2020.120421

[9] Majhi, R. K., \& Nayak, A. N. (2020). Production of sustainable concrete utilising high-volume blast furnace slag and recycled aggregate with lime activator. Journal of Cleaner Production, 255, 120188. doi:10.1016/j.clepro.2020.120188

[10] Chatterjee, A., \& Sui, T. (2019). Alternative fuels - Effects on clinker process and properties. Cement and Concrete Research, 123, 105777. doi:10.1016/j.cemconres.2019.105777

[11] Bostanci, S. C. (2020). Use of marble dust and recycled glass for sustainable concrete production. Journal of Cleaner Production, 251, 119785. doi:10.1016/j.jclepro.2019.119785

[12] De Brito, L., P., V., de Figueiredo, A., D., Moriggi, T., John, V., M. (2019).Waste generation from the production of readymixed concrete. Waste Management, 94, 146-152. doi: 10.1016/j.wasman.2019.05.043

[13] Oyebisi, S., Igba, T., \& Oniyide, D. (2019). Performance evaluaton of cashew nutshell ash as a binder in concrete production. Case Studies in Construction Materials, 11, e00293. doi:10.1016/j.cscm.2019.e00293

[14] Mokhtar, A., N., M. (2020). A decision support tool for cement industry to select energy efficiency measures. Energy Strategy Reviews, 28, 100458. 10.1016/j.esr.2020.100458

[15] Singh, N., B., Kumar, M., Rai, S. (2020). Geopolymer cement and concrete: Properties. Materials Today: Proceedings, 29, 743-748. doi: 10.1016/j.matpr.2020.04.513

[16] Amran, Y. M., Alyousef, R., Alabduljabbar, H., \& El-Zeadani, M. (2020). Clean production and properties of geopolymer concrete: a review. Journal of Cleaner Production, 251, 119679. doi:10.1019/j.clepro.2019.119679

[17] Garside, M. (2020). Global cement production 1995-2019. https://www.statista.com/statistics/1087115/global-cementproduction-volume/

[18] Edwards, P., \& Perilli, D. (2020). Global cement News. Global Cement Magazine, 41, 23-24. Retrieved from https://www.globalcement.com/pdf/3dgcjulaug20/

[19] Seo, M., Lee, S., -Y., Lee, C., Cho, S., -S. (2019). Recycling of cement kiln dust as a raw material for cement.Environments, 6 (10), 113.doi: 10.3390/environments6100113

[20] USGS. (2020). National Minerals Information Center, U. (n.d.). mcs2020.pdf - Mineral Commodity Summaries 2020.

[21] Bildirici, M., E. (2019). Cement production, environmental pollution, and economic growth: evidence from China and USA. Clean Technologies and Environmental Policy, 21 (4), 783-793. doi: 10.1007/s10098-019-01667-3 
[22] Hagemann, S., E., Gastaldini, A., L., G., Cocco, M., Jahn, S., L., Terra, L., M. (2019). Synergic effects of the substitution of Portland cement for water treatment plant sludge ash and ground limestone: Technical and economic evaluation. Journal of Cleaner Production, 214, 916-926. doi: 10.1016/j.jclepro.2018.12.324

[23] Ince, C. (2019). Reusing gold-mine tailings in cement mortars: Mechanical properties and socio-economic developments for the Lefke-Xeros area of Cyprus.Journal of Cleaner Production, 238, 117871.doi: 10.1016/j.clepro.2019.117871

[24] CSI. (2019). Cement Sustainability Initiative. GNR SCI Project Reporting CO2.Getting the Numbers Right, WBSCD. Banco de dados. http://www.wbcsdcement.org/GNR-2016/.

[25] ROADMAP. (2019). In: Visedo, G., Pecchio, M. (Eds.), Cement Technology: Potential to Reduce Carbon Emissions in the Brazilian Cement Industry by 2050. SNIC, Rio de Janeiro.

[26] IEA. (2019). Direct CO2 Intensity of Cement in the Sustainable Development Scenario, 2014-2030. IEA, Paris.

[27] MugahedAmran, Y., H., Alyousef, R., Alabduljabbar, H., El-Zeadani, M. (2020).Clean production and properties of geopolymer concrete; A review.Journal of Cleaner Production, 251, 119679.doi: 10.1016/j.jclepro.2019.119679

[28] Hache, E., Simoën, M., Seck, G., S., Bonnet, C., Jabberi, A., Carcanague, S. (2020). The impact of future power generation on cement demand: An international and regional assessment based on climate scenarios. International Economics, 163, 114-133. doi: 10.1016/j.inteco.2020.05.002

[29] Bassani, M., Diaz Garcia, J. C., Meloni, F., Volpatti, G., \& Zampini, D. (2019). Recycled coarse aggregates from pelletized unused concrete for a more sustainable concrete production. Journal of Cleaner Production, 219, 424-432. doi:10.1016/j.jclepro.2019.01.338

[30] Mohammed, S., I., Najim, K., B. (2020). Mechanical strength, flexural behavior and fracture energy of Recycled Concrete Aggregate self-compacting concrete. Structures, 23, 34-43. doi: 10.1016/j.istruc.2019.09.010

[31] Arora, S., Singh, S., P. (2019). Probability of failure of RCA concrete with ternary blended cements. Construction and Building Materials, 225, 401-414. 10.1016/j.conbuildmat.2019.07.205

[32] UNEP. (2019). Sand_and_sustainability_UNEP_2019.pdf.

[33] Freedonia Group, World construction aggregates to 2019, Cleveland, 2016.

[34] Liu, B., Feng, C., Deng, Z. (2019). Shear behavior of three types of recycled aggregate concrete. Construction and Building Materials, 217, 557-572. doi: 10.1016/j.conbuildmat.2019.05.079

[35] Kumar, G., S. (2019). Influence of fluidity on mechanical and permeation performances of recycled aggregate mortar. Construction and Building Materials, 213, 404-412. doi: 10.1016/j.conbuildmat.2019.04.093

[36] Kirthika, S. K., Surya, M., \& Singh, S. K. (2019). Effect clay in alternative fine aggregates on performance of concrete. Construction and Building Materials, 228, 116811. doi:10.1016/j.conbuildmat.2019.116811

[37] Muthusamy, K., Mirza, J., Zamri, N., A., Hussin, M., W., Abdul Majeed, P., P., Kusbiantoro, A., Mokhtar, AlbshirBudie, A. (2019). Properties of high strength palm oil clinker lightweight concrete containing palm oil fuel ash in tropical climate. Construction and Building Materials, 199, 163-177.

[38] HajarSaharudin, S., HaslindaShariffuddin, J., Ida AmalinaAhamadNordin, N., Ismail, A. (2019). Effect of aging time in the synthesis of biogenic hydroxyapatite derived from cockle shell. Materials Today: Proceedings, 19 (4), 1208-1215. doi: 10.1016/j.matpr.2019.11.124

[39] Carss, D., N., Brito, A., C., Chainho, P., Ciutat, A., de Montaudouin, X., Otero, R., M., F., Filgueira, M., I., Garbutt, A., Goedknegt, M., A., Lynch, S., A., Mahony, K., E., Maire, O., Malham, S., K., Orvain, F., der Schatte Olivier, A., Jones, L. (2020). Ecosystem services provided by a non-cultured shellfish species: The common cockle Cerastodermaedule. Marine Environmental Research, 158, 104931.doi: 10.1016/j.marenvres.2020.104931

[40] Food and Agriculture Organization of the United Nations., International Fund for Agricultural Development, UNICEF, World Food Programme, \& World Health Organization. (n.d.). The state of food security and nutrition in the world: safeguarding against economic slowdowns and downturns.

[41] Ramakrishna, B., \& Sateesh, A. (2016). Exploratory study on the use of cockle shell as partial coarse \& fine aggregatereplacement in concrete. International Research Journal of Engineering and Technology (IRJET), 3(6), 2347-2349.

[42] Mouritsen, K. N. (2004). Intertidal facilitation and indirect effects: Causes and consequences of crawling in the New Zealand cockle. Marine Ecology Progress Series, 271, 207-220. https://doi.org/10.3354/meps271207

[43] Ezahtul Shahreen Ab Wahab, R. H. (2015). Compressive strength of concrete added with cockle sells as sand replacement. Acta Universitatis Agriculturae et Silviculturae Mendelianae Brunensis, 53(9), 1689-1699. http://publications.lib.chalmers.se/records/fulltext/245180/245180.pdf\%0Ahttps://hdl.handle.net/20.500.12380/245180\%0Ah ttp://dx.doi.org/10.1016/j.jsames.2011.03.003\%0Ahttps://doi.org/10.1016/j.gr.2017.08.001\%0Ahttp://dx.doi.org/10.1016/j.pr ecamres.2014.12

[44] kumar, P. S., kumar, C. S., Yuvaraj, P., kumar, B. M., \& mohan, E. K. J. (2016). A Partial Replacement for Coarse Aggregate by Sea Shell and Cement by Lime in Concrete. 2016, 2(5), 1131-1136. Retrieved from http://www.imperialjournals.com/index.php/IJIR/article/view/617

[45] Muthusamy, K., Sabri, N. a, Resources, E., \& Razak, L. T. (2012). Cockle Shell : A Potential Partial Coarse Aggregate Replacement In Concrete. International Journal of Science, Environment and Technology, 1(4), 260-267.

[46] Soltanzadeh, F., Emam-Jomeh, M., Edalat-Behbahani, A., \& Soltan-Zadeh, Z. (2018). Development and characterization of blended cements containing seashell powder. Construction and Building Materials, 161, $292-304$. https://doi.org/10.1016/j.conbuildmat.2017.11.111 
[47] Lertwattanaruk, P., Makul, N., \& Siripattarapravat, C. (2012). Utilization of ground waste seashells in cement mortars for masonry and plastering. Journal of Environmental Management, 111, 133-141. https://doi.org/10.1016/j.jenvman.2012.06.032

[48] Azmi, M., \& Johari, M. (2013). Cockle Shell Ash Replacement for Cement and Filler in Concrete. Cockle Shell Ash Replacement for Cement and Filler in Concrete, 25(2), 201-211. https://doi.org/10.11113/mjce.v25n2.303

[49] Olivia, M., Mifshella, A. A., \& Darmayanti, L. (2015). Mechanical properties of seashell concrete. Procedia Engineering, 125, 760-764. https://doi.org/10.1016/j.proeng.2015.11.127

[50] Olivia, M., Oktaviani, R., \& Ismeddiyanto. (2017). Properties of Concrete Containing Ground Waste Cockle and Clam Seashells. Procedia Engineering, 171, 658-663. https://doi.org/10.1016/j.proeng.2017.01.404

[51] Khankhaje, E., Rafieizonooz, M., Salim, M. R., Mirza, J., Salmiati, \& Hussin, M. W. (2017a). Comparing the effects of oil palm kernel shell and cockle shell on properties of pervious concrete pavement. International Journal of Pavement Research and Technology, 10(5), 383-392. https://doi.org/10.1016/j.ijprt.2017.05.003

[52] Khankhaje, E., Salim, M. R., Mirza, J., Salmiati, Hussin, M. W., Khan, R., \& Rafieizonooz, M. (2017b). Properties of quiet pervious concrete containing oil palm kernel shell and cockleshell. Applied Acoustics, 122, $113-120$. https://doi.org/10.1016/j.apacoust.2017.02.014

[53] Raju, P. M., \& Siva, S. (2016). Compressive Strength of Concrete With Partial Replacement of Aggregates With Granite Powder and Cockle Shell, 28(2). https://doi.org/10.11113/mjce.v28n2.420

[54] Al-zubaidi, A. B., Abass, R. U., \& Al-tabbakh, A. A. (2015). Mechanical and thermal properties of cockles shell cementing material. Iraqi Journal of Physics, 13(26), 107-111.

[55] Hazurina, N. O. R., Bakar, A. B. U., Johari, M., \& Don, M. A. T. (2013). AWAM International Conference on Civil Engineering \& Geohazard Information Zonation Potential Use of Cockle ( Anadara granosa ) Shell Ash as Partial Cement Replacement in Concrete, 2(October 2015), 369-376.

[56] Mohamed, M., Yousuf, S., \& Maitra, S. (2012). Decomposition study of calcium carbonate in cockle shell. Journal of Engineering Science and Technology, 7(1), 1-10.

[57] Martínez-García, C., González-Fonteboa, B., Martínez-Abella, F., \& Carro- López, D. (2017). Performance of mussel shell as aggregate in plain concrete. Construction and Building Materials, 139, 570-583. https://doi.org/10.1016/j.conbuildmat.2016.09.091

[58] Mo, K. H., Alengaram, U. J., Jumaat, M. Z., Yap, S. P., \& Lee, S. C. (2016). Green concrete partially comprised of farming waste residues: A review. Journal of Cleaner Production, 117, 122-138. https://doi.org/10.1016/j.jclepro.2016.01.022

[59] Safi, B., Saidi, M., Daoui, A., Bellal, A., Mechekak, A., \& Toumi, K. (2015). The use of seashells as a fine aggregate (by sand substitution) in self-compacting mortar (SCM). Construction and Building Materials, 78, 430-438. https://doi.org/10.1016/j.conbuildmat.2015.01.009

[60] Beng Wei, C., Othman, R., Yee Ying, C., Putra Jaya, R., Shu Ing, D., \& Ali Mangi, S. (2020). Properties of mortar with fine eggshell powder as partial cement replacement. Materials Today: Proceedings, (xxxx). https://doi.org/10.1016/j.matpr.2020.07.240

[61] Awang Junaidi, Awang Hazmi and Abu Bakar Zakaria, Md Zuki and Mohamed Mustapha, Noordin and Abu, Jalila and Yusof, N. (2007). Mineral composition of the cockle (Anadara granosa) shells of West Coast of Peninsular Malaysia and it's potential as biomaterial for use in bone repair. UPM Institutional Repository, 6(5), 591-594. https://doi.org/javaa.2007.591.594

[62] Nanstad, R. K. (1976). Review of concrete properties for prestressed concrete pressure vesssels United States

[63] Shariza, M. A., Carlos Philip, D., \& Mohsin Sharifah Maszura, S. (2019). Preliminary Study on Properties of Oil Palm Shell Lightweight Concrete with Cockle Shell as Mixing Ingredient. IOP Conference Series: Materials Science and Engineering, 601(1). https://doi.org/10.1088/1757-899X/601/1/012016

[64] Razali, N. (2017). Utilization of Cockle Shells as Partial Binder Replacement. Journal of Engineering and Technology, 8(2), $0-0$. 